\title{
Original
}

\section{A Novel Mutation of the Arginine Vasopressin Receptor 2 Gene in a Patient with Congenital Nephrogenic Diabetes Insipidus}

\author{
Asako Tajima ${ }^{1}$, Ichiro Miyata1 ${ }^{1}$, Akira Katayama², Shigeru Toyoda ${ }^{2}$ and Yoshikatsu Eto ${ }^{1}$ \\ ${ }^{1}$ Department of Pediatrics, The Jikei University School of Medicine, Tokyo, \\ ${ }^{2}$ Department of Pediatrics, Kanagawa Prefecture Midwives and Nurses Training School Hospital, Yokohama, Japan
}

\begin{abstract}
We have identified a novel mutation of the arginine vasopressin receptor 2 (AVPR2) gene in a case of congenital X-linked nephrogenic diabetes insipidus (NDI). The patient was a 2-mo-old Japanese boy with persistent fever and failure to thrive. He was diagnosed as having congenital NDI by clinical and laboratory findings. Molecular analysis demonstrated that he was hemizygous for a $\mathrm{G}$ to $\mathrm{C}$ transversion in exon 2 of the AVPR2 gene which resulted in a glycine to arginine substitution (G107R) at the 107th codon of the first extracellular loop. His mother was heterozygous for the same mutation. We speculated that the G107R mutation would interfere with the binding capacity of the AVPR2, since G107R is located near F105 and R106, both of which are crucial for ligand binding. In cases of X-linked NDI, mutations in the AVPR2 gene are distributed widely. Thus, DNA analysis throughout the gene is of clinical value for the identification of female carriers, and it also gives precise information for genetic counseling.
\end{abstract}

Key words: nephrogenic diabetes insipidus (NDI), arginine vasopressin receptor 2 (AVPR2) gene, novel mutation

\section{Introduction}

Congenital nephrogenic diabetes insipidus (NDI) has at least 3 types of inheritance: X-linked, autosomal recessive, and autosomal dominant. The X-linked type is caused by mutation of the arginine vasopressin receptor 2 (AVPR2) gene that is located in chromosome region $\mathrm{Xq} 28$, and codes for the vasopressin V2 receptor. The other two types are due to mutations of the aquaporin-2

Received: July 1, 2004

Accepted: October 20, 2004

Correspondence: Dr. Asako Tajima, Department of Pediatrics, The Jikei University School of Medicine, 3-25-8

Nishi-shinbanshi, Minato-ku, Tokyo 105-8461, Japan

E-mail: atajima@jikei.ac.jp
(AQP2) gene that is located in chromosome region $12 q 13$, and codes for the vasopressin-sensitive water channel $(1,2)$.

To date, 178 mutations in the AVPR2 gene have been identified in cases with X-linked NDI, according to the Human Gene Mutation Database (http://archive.uwcm.ac.uk/uwcm/mg/ hgmd0.html). In vitro studies of mutant AVPR2 proteins have clarified the mechanism of loss of function or dysregulation. Genetic analysis for patients with congenital NDI is necessary, since asymptomatic female carriers can be detected.

In this paper we describe a 2-mo-old Japanese male patient with congenital X-linked NDI. He was a hemizygote for a novel mutation in exon 2 of the AVPR2 gene. 
Table 1 Laboratory data on admission

Peripheral blood, blood chemistry and serology

\begin{tabular}{lclrlr}
\hline WBC & $16300 / \mathrm{mm}^{3}$ & AST & $35 \mathrm{IU} / \mathrm{L}$ & $\mathrm{Na}$ & $152.0 \mathrm{mEq} / \mathrm{L}$ \\
Gran & $34 \%$ & ALT & $27 \mathrm{IU} / \mathrm{L}$ & $\mathrm{K}$ & $4.5 \mathrm{mEq} / \mathrm{L}$ \\
Lym & $61 \%$ & LDH & $507 \mathrm{IU} / \mathrm{L}$ & $\mathrm{Cl}$ & $110.0 \mathrm{mEq} / \mathrm{L}$ \\
Mono & $3 \%$ & $\mathrm{CK}$ & $30 \mathrm{IU} / \mathrm{L}$ & $\mathrm{Ca}$ & $4.9 \mathrm{mEq} / \mathrm{L}$ \\
Eosino & $2 \%$ & $B U N$ & $11.7 \mathrm{mg} / \mathrm{dl}$ & $\mathrm{P}$ & $6.4 \mathrm{mg} / \mathrm{dl}$ \\
RBC & $327 \times 10^{4} / \mathrm{mm}^{3}$ & $\mathrm{Cr}$ & $0.5 \mathrm{mg} / \mathrm{dl}$ & $\mathrm{CRP}$ & $0.4 \mathrm{mg} / \mathrm{dl}$ \\
$\mathrm{Hb}$ & $9.7 \mathrm{~g} / \mathrm{dl}^{2}$ & $\mathrm{ALP}$ & $16.8 \mathrm{IU} / \mathrm{L}$ & & \\
$\mathrm{Hct}$ & $28.7 \%$ & & & & \\
Plt & $28.0 \times 10^{4} / \mathrm{mm}^{3}$ & & & & \\
\hline
\end{tabular}

\begin{tabular}{lr} 
Blood gas analysis \\
\hline $\mathrm{pH}$ & 7.431 \\
$\mathrm{paCO}_{2}$ & 36.7 \\
$\mathrm{paO}_{2}$ & 106.2 \\
$\mathrm{HCO}_{3}{ }^{-}$ & 24.4 \\
$\mathrm{BE}$ & 0.6 \\
$\mathrm{SaO}_{2}$ & 95.0 \\
& \\
\hline
\end{tabular}

\begin{tabular}{lr} 
Urinalysis & \\
\hline$S G$ & 1.005 \\
pH & 7.5 \\
Protein & - \\
Sugar & - \\
Blood & - \\
RBC & $0-1 / \mathrm{HPF}$ \\
WBC & $0-1 / \mathrm{HPF}$ \\
\hline
\end{tabular}

Endocrine test

\begin{tabular}{lcl}
\hline ADH & $\geq 13.0 \mathrm{pg} / \mathrm{ml}$ & $(0.3-3.5)$ \\
$P R A$ & $7.7 \mathrm{ng} / \mathrm{ml} / \mathrm{h}$ & $(0.3-2.9)$ \\
Aldosterone & $175.0 \mathrm{pg} / \mathrm{ml}$ & $(36-240)$ \\
HANP & $30 \mathrm{pg} / \mathrm{ml}$ & $(29-74)$ \\
\hline
\end{tabular}

HANP: Human atrial natriuretic peptide.

\section{Case Report}

A 2-mo-old boy was admitted to our hospital presenting with persistent fever and a poor weight gain. He was born at 40 weeks' gestation, weighing $3110 \mathrm{~g}$ with no problems during the perinatal period. There was no family history of NDI. At 1 mo of age, his poor weight gain was observed. In addition, his mother noticed an unexplained recurrent fever from around 50 days of age. To determine the causes of his problems, he was referred to our hospital at $83 \mathrm{~d}$ of age.

On admission, his body length was $59 \mathrm{~cm}(-0.4$ SD), his body weight was $4640 \mathrm{~g}(-1.8 \mathrm{SD})$, and his head circumference was $41 \mathrm{~cm}(+0.7 \mathrm{SD})$; BMI was 13.3. His body temperature was $38.2^{\circ} \mathrm{C}$ and blood pressure was 110/50 mmHg. His lips were slightly dry. There were no abnormal findings upon chest and abdominal examination. Skin turgor was normal and his anterior fontanel was not distended or sunken. There were no abnormal neurological signs.

The results of laboratory findings on admission are summarized in Table 1. Hemoglobin (Hb) was $9.7 \mathrm{~g} / \mathrm{dl}$, white blood cells (WBC) 16300/ $\mathrm{mm}^{3}$, serum creatinine $0.5 \mathrm{mg} / \mathrm{dl}$, serum sodium $152 \mathrm{mEq} / \mathrm{l}$, and chloride $110 \mathrm{mEq} / \mathrm{l}$, respectively. C-reactive protein (CRP) was not elevated. Arterial 
Table 2 Water deprivation test (A) and pitressin loading test (B)

\begin{tabular}{lcc}
\hline (A) & Before & \multicolumn{1}{c}{$4 \mathrm{~h}$} \\
\hline Urine volume (ml/h) & 24 & 32 \\
U-osm (mOsm/kg) & 58 & 96 \\
P-osm (mOsm/kg) & 284 & 295 \\
U/P-osm & 0.20 & 0.33 \\
P-ADH (pg/ml) & 15.2 & 24.2 \\
\hline (B) & Before & $3 \mathrm{~h}$ \\
\hline Urine volume (ml/h) & 50 & 50 \\
U-osm (mOsm/kg) & 34 & 44 \\
P-osm (mOsm $/ \mathrm{kg})$ & 271 & 271 \\
U/P-osm & 0.13 & 0.16 \\
U-cAMP (pmol/ml) & 333 & 371 \\
\hline
\end{tabular}

blood gas values were within normal limits. The specific gravity of urine was significantly low. On endocrinological examination, plasma arginine vasopressin (AVP) was markedly increased (>13.0 $\mathrm{pg} / \mathrm{ml}$ ) and plasma renin activity (PRA) was also elevated $(7.7 \mathrm{ng} / \mathrm{ml} / \mathrm{hr})$. In the water deprivation test, the response of urine osmolality was impaired. Furthermore, subcutaneous administration of arginine vasopressin did not increase either urine osmolality or cAMP (Table 2). Brain magnetic resonance imaging (MRI) showed normal pituitary gland and pituitary stalk. High intensity of the posterior lobe was detected on the T1-weighted image.

On the basis of these findings, the boy was diagnosed as having congenital NDI. Therapy was initiated with intravenous fluid administration, oral intake of hydrochlorothiazide (2-3 mg/ $\mathrm{kg} /$ day), as well as a low sodium diet. A low protein diet was not chosen in order to avoid malnutrition and growth delay. The water balance before starting the diuretics was $1500-1700 \mathrm{ml} /$ day intake (including milk and drip infusion) and 1000-1500 ml/day urination, but after the initiation of the therapy, fluid intake reduced to 1000-1300 ml/day and urine decreased to 500$800 \mathrm{ml} /$ day. Serum electrolytes and osmolality returned to normal levels within a few weeks, and the boy's condition became well controlled. After about 6 mo of treatment, he showed a normal average weight for his age. Coagulation factor VIII was $86 \%$ and von Willebrand factor was $98 \%$.

\section{Genetic Analysis}

For the genetic assessment, informed consent was first obtained from his parents. An institutional review board was not yet established at the time of the analysis, so the explanation and the discussion for the consent was based on the Helsinki Final Act of 1975. Genomic DNA was extracted from white blood cells of the patient and his mother with standard procedures. Five overlapping fragments encompassing the three coding exons of the AVPR2 gene were amplified by PCR, using the oligonucleotide primers described in a previous publication (3). The primers were located at nt 189 through 208 (A), nt 665 through 686 (B), nt 255 through 260 and nt 622 through 636 (C), nt 984 through 1003 (D), nt 904 through 923 (E), nt 1362 through 1381 (F), nt 1284 through 1307 (G), nt 1795 through 1814 (H), nt 1512 through $1530(\mathrm{I})$, and nt 1852 through $1871(\mathrm{~J})$ (NCBI accession number L22206, gi:347522). Locations and oligonucleotide sequences of the PCR primers $(A \sim J)$ are shown in Fig. 1. The predicted length of the PCR products was $497 \mathrm{bp}$ for A-B primers, $388 \mathrm{bp}$ for C-D, $478 \mathrm{bp}$ for E-F, 530 bp for G-H and $358 \mathrm{bp}$ for I-J. To screen for mutations, single-strand conformational polymorphism (SSCP) was performed for all of the PCR-amplified fragments, using the GeneGel Excel 12.5/24 Kit (Amersham Biosciences). This procedure was chosen because it shows a difference of 6-8 bps in forms of separate bands in the fragments of 50-500 bps. The PCR products that resulted positive on the SSCP analysis were subjected to direct sequencing by an automated DNA sequencer to detect mutation. In addition, to confirm the presence of the mutation, these products were digested with restriction enzyme at 


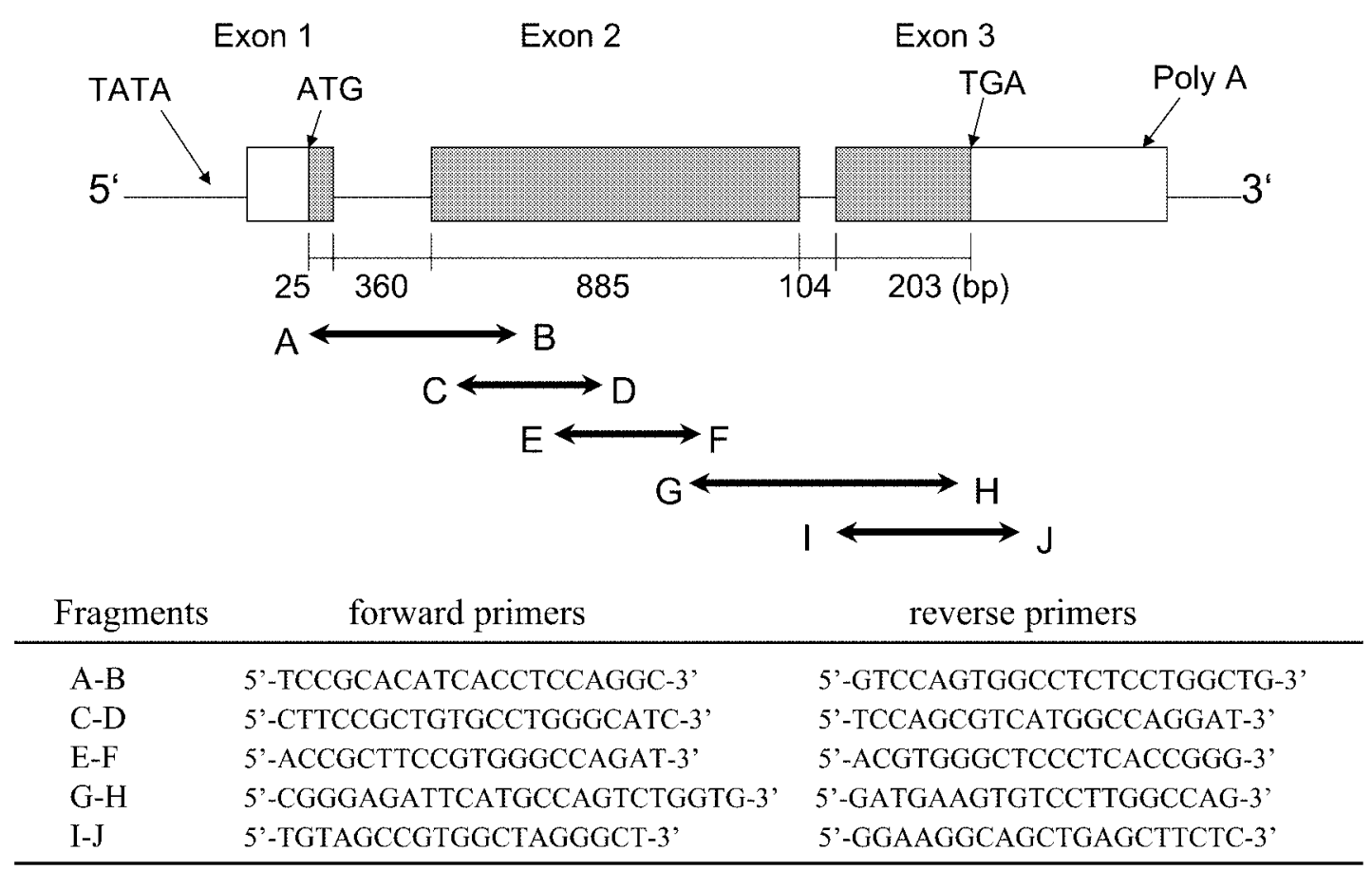

Fig. 1 The structure of the AVPR2 gene, the expected PCR fragments and the primers.

$37^{\circ} \mathrm{C}$ for $3 \mathrm{hrs}$, and electrophoresed in $20 \%$ polyacrylamide gel (PAGE) for $3 \mathrm{hrs}$.

\section{Results}

In the SSCP analysis, shifted bands were found in the second fragments (amplified with primers $\mathrm{C}$ and $\mathrm{D}$ ) of both the patient and his mother (Fig. 2). On the other hand, there was no difference between the samples in other fragments. The direct sequencing revealed a novel mutation in exon 2 of their AVPR2 gene. As shown in Fig. 2, the mutation was a $\mathrm{G}$ to $\mathrm{C}$ transversion, which results in a glycine to arginine substitution at the 107th codon of the first extracellular loop of the AVPR2 protein (G107R). In order to prove the mutation was G107R, restriction enzyme analysis with BtgI was performed. The recognition site for BtgI (C/CXYGG ( $X$ : A or G, $Y$ : C or T)) is destroyed in the mutated sequence (Fig. 2), so if the fragments are digested with BtgI, the sample without the mutation should make 3 fragments, whereas the sample with the mutation should make 2 fragments. This matched the results of our case in electrophoresis, in which there were 2 bands (217 bp and $146 \mathrm{bp}$ ) in the patient, 4 (217 bp, $146 \mathrm{bp}, 91 \mathrm{bp}$ and $55 \mathrm{bp}$ ) in his mother, and 3 (217 bp, $91 \mathrm{bp}$ and $55 \mathrm{bp}$ ) in the control (Fig. 3). These findings suggest that the patient is a hemizygote and his mother a heterozygote, for this G107R mutation, confirming that the mode of inheritance was X-linked recessive.

\section{Discussion}

NDI is characterized by inability to concentrate urine, despite normal or elevated plasma concentration of AVP. Polyuria, with hyposthenuria and polydipsia are the main clinical manifestations of the disease. In early infancy, hypernatremia, hyperthermia, mental retardation, and repeated episodes of dehydration can also be seen. NDI is clinically distinguishable from other forms of inherited diabetes insipidus, such as 


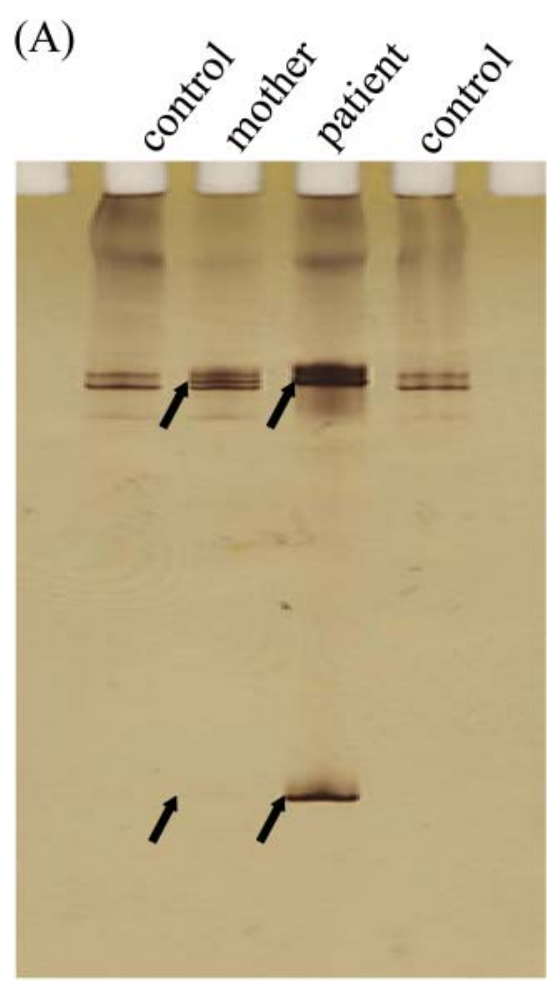

(B) Patient: hemizygous

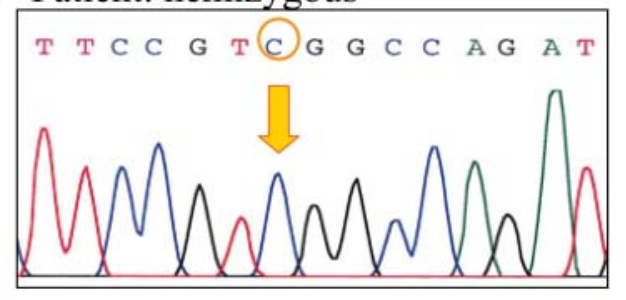

Mother: heterozygous
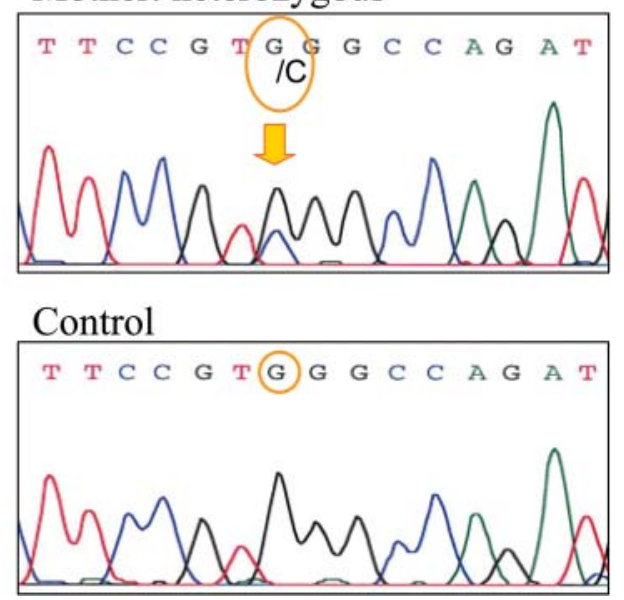

Fig. 2 SSCP analysis and the direct sequencing. (A) Shifted bands were found in exon 2 of the AVPR2 gene. (B) Direct sequencing showed a G-to-C transversion in the patient and the mother.

central diabetes insipidus, by the lack of response to exogenous AVP and by plasma levels of AVP that normally rise, with increase in plasma osmolality. Among the patients with congenital NDI, about $90 \%$ are males with the X-linked recessive form. On the other hand, the autosomal recessive and dominant mode of inheritance are seen in less than $10 \%$ of the families with mutations of the AQP2 gene.

The AVPR2 gene has 3 exons and 2 small introns. The cDNA sequence predicts a polypeptide of 371 amino acids with seven transmembranes, four extracellular, and four cytoplasmic domains that belong to the family of Gprotein coupled receptors. There are 178 putative disease-causing AVPR2 mutations that have been identified in 250 families, so far (Data obtained from the Human Gene Mutation Database and the
Nephrogenic Diabetes Insipidus Mutation Database, http://www.medicine.mcgill.ca/ nephros/). These mutations have been detected in every domain, and half of them are missense mutations. Functional analysis of these AVPR2 mutations has shown two abnormalities. In most of the AVPR2 mutations, the mutated receptors are retained in cytoplasm and cannot fold into the plasma membrane. The other abnormality is the inability of the mutated receptors to bind AVP or to transduce the intracellular cAMP signal to the postreceptor pathway, even though they reach the cell surface. Recently, experimental trials using a small-molecule antagonist or adenovirus-mediated gene transfer have been begun for rescuing mutated AVPR2 (5-7).

The 107th codon codes for an amino acid in the first extracellular loop of the AVPR2. In 1997, 


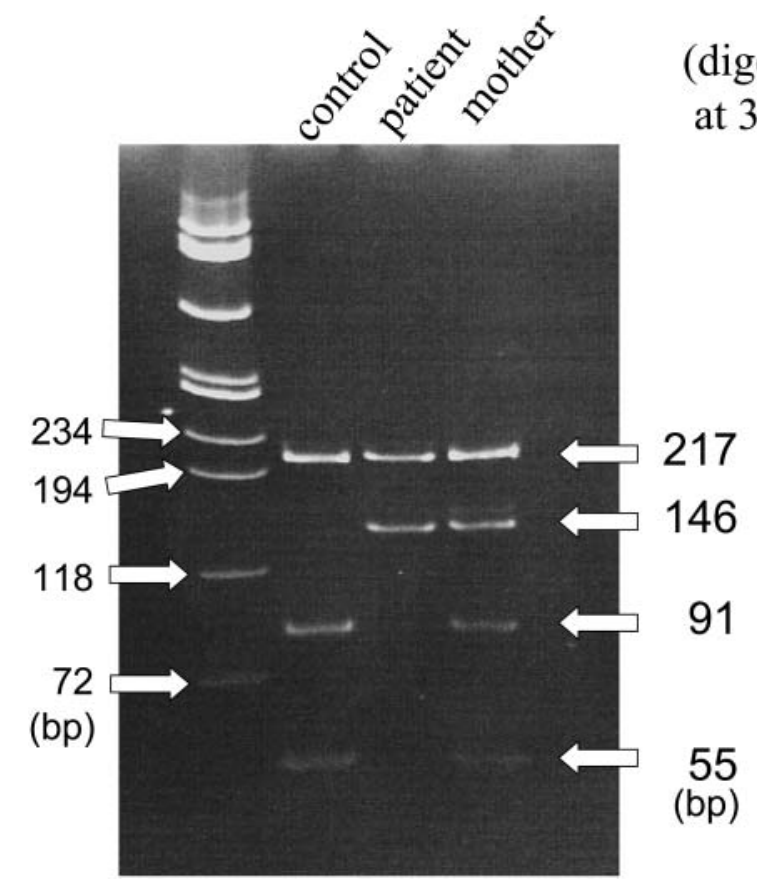

\section{(digested with BtgI, at $37^{\circ} \mathrm{C}$ for 3 hours)}

Fig. 3 Detection of G107R by restriction enzyme method.

Vargas-Poussou et al. identified a novel mutation at the same codon (107-2G $\rightarrow \mathrm{A} ; \mathrm{G} 107 \mathrm{E})$ (8). A similar change is recognized as characteristic of the amino acid between G107R and G107E mutations, in which glycine is non-polar and hydrophobic, but arginine and glutamic acid are polar and hydrophilic. However, in vitro studies for G107R or G107E mutant have not yet been carried out. Recently, three adjacent mutations (R104C, F105V and R106C) have been reported from different groups, and their functional studies showed that these mutations interfere with the binding capacity of AVPR2 or with the production of cAMP $(9,10)$. Furthermore, Pasel et al. have pointed out that F105 and F106 of the AVPR2 protein are the amino acids crucial for binding of ligand (9). Based on the evidence, we speculate that the G107R mutation would interfere with the binding capacity of the AVPR2. To elucidate the function of the G107R mutant, further studies are necessary.

In cases of congenital X-linked NDI, DNA analysis should be performed throughout the AVPR2 gene. Knowing the existence of AVPR2 mutations in NDI families is of clinical value because it will be helpful in identifying female carriers who have been asymptomatic, and precise information is also essential for the genetic counseling.

\section{References}

1. Bichet D. Nephrogenic diabetes insipidus. Am J Med 1998; 105: 431-42.

2. Sasaki S. Nephrogenic diabetes insipidus: update of genetic and clinical aspects. Nephrol Dial Transplant 2004; 19: 1351-3.

3. Tsukaguchi H, Matsubara H, Aritaki S, Kimura T, Abe S, Inada M. Two novel mutations in the vasopressin V2 receptor gene in unrelated Japanese kindreds with nephrogenic diabetes insipidus. Biochem Biophys Res Commun 1993; 197: 1000-10.

4. Knoers N, Deen P. Molecular and cellular defects in nephrogenic diabetes insipidus. Pediatr 
Nephrol 2001; 16: 1146-52.

5. Schoneberg T, Sandig V, Wess J, Gudermann T, Schultz G. Reconstitution of mutant V2 vasopressin receptors by adenovirus-mediated gene transfer. Molecular basis and clinical implication. J Clin Invest 1997; 100: 1547-56.

6. Morello J, Salahpour A, Laperriere A, Bernier V, Arthus M, Lonergan M, et al. Pharmacological chaperones rescue cell-surface expression and function of misfolded V2 vasopressin receptor mutants. J Clin Invest 2000; 105: 887-95.

7. Sangkuhl K, Schultz A, Römpler H, Yun J, Wess J, Schöneberg T. Aminoglycoside-mediated rescue of a disease-causing nonsense mutation in the V2 vasopressin receptor gene in vitro and in vivo. Hum Mol Genet 2004; 13: 893-903.
8. Vargas-Poussou R, Forestier L, Dautzenberg M, Niaudet P, Dechaux M, Antignac C. Mutations in the vasopressin V2 receptor and aquaporin-2 genes in 12 families with congenital nephrogenic diabetes insipidus. J Am Soc Nephrol 1997; 8: 1855-62.

9. Pasel K, Schulz A, Timmermann K, Linnemann K, Hoeltzenbein M, Jaaskelainen J, et al. Functional characterization of the moleculalr defects causing nephrogenic diabetes insipidus in eight families. J Clin Endocrinol Metab 2000; 85: 1703-10.

10. Inaba S, Hatakeyama H, Taniguchi N, Miyamori I. The property of a novel V2 receptor mutant in a patient with nephrogenic diabetes insipidus. J Clin Endocrinol Metab 2001; 86: 381-5. 